\title{
Corpus
}

\section{Los Papeles de Analco: poder, prestigio y lucha por la tierra en la Sierra Norte de Oaxaca}

Papeles de Analco: power, prestige and the struggle for land in the Sierra Norte de Oaxaca

\section{Raquel E. Güereca Durán}

\section{(Q) OpenEdition}

\section{Electronic version}

URL: http://journals.openedition.org/corpusarchivos/4141

DOI: 10.4000/corpusarchivos. 4141

ISSN: 1853-8037

\section{Publisher}

Diego Escolar

\section{Electronic reference}

Raquel E. Güereca Durán, « Los Papeles de Analco: poder, prestigio y lucha por la tierra en la Sierra Norte de Oaxaca », Corpus [En línea], Vol. 10, №. 2 | 2020, Publicado el 17 diciembre 2020, consultado el 29 diciembre 2020. URL : http://journals.openedition.org/corpusarchivos/4141 ; DOI : https:// doi.org/10.4000/corpusarchivos.4141

This text was automatically generated on 29 December 2020 . 


\section{Los Papeles de Analco: poder, prestigio y lucha por la tierra en la Sierra Norte de Oaxaca}

Papeles de Analco: power, prestige and the struggle for land in the Sierra Norte de Oaxaca

Raquel E. Güereca Durán

\section{EDITOR'S NOTE}

Fecha de recepción del original: 25/08/2020

Fecha de aceptación para publicación: 18/11/2020

\section{Analco: un enclave nahua en la Sierra Norte}

Desde tiempos prehispánicos, la región conocida como Sierra Norte en el estado de Oaxaca, México, ha estado habitada por indígenas hablantes de chinanteco, mixe y zapoteco. Estos últimos, a su vez, se subdividen en tres variantes lingüísticas: bixanos, cajonos y nexitzos. Hoy en día, el número de hablantes de una lengua indígena en la región está muy encima del promedio estatal: $76 \%$ contra $35 \%$, respectivamente. De igual modo, un $92 \%$ de los habitantes de la Sierra Norte se consideran indígenas, frente al 62\% del promedio del estado (COPLADE, 2017, p. 4).

2 Al día de hoy, no hay registro de que en esta región oaxaqueña habiten hablantes de náhuatl; los únicos nahua hablantes del estado se localizan al norte, en la Sierra Mazateca, colindando con el estado de Puebla. No obstante, durante el periodo colonial existió un pequeño enclave de indios nahuas, cuya relevancia fue mayúscula en la consolidación del dominio colonial en la región: me refiero a los indios, denominados genéricamente "mexicanos", de Analco. 
3 Nuestra Señora del Rosario Analco fue un barrio ubicado en los arrabales de la Villa Alta de San Ildefonso, en la Sierra Norte de Oaxaca (ver mapa 1). Fue fundado en algún momento del siglo XVI por los naturales que fungieron como auxiliares militares de las diversas campañas enviadas desde la Ciudad de México para someter la región. Particularmente, es probable que se tratara de los indios que acompañaron las tres entradas que planeó Hernán Cortés en 1526 para conquistar una tierra que había resultado sumamente difícil de someter. $Y$ es que las "sierras de los zapotecas y mixes" eran, según Bernal Díaz del Castillo "tan agrias y malas que no pueden ir por ellas caballos, y los soldados habían de ir a pie por unas sendas muy angostas, por contadero uno a uno, y siempre hay neblinas y rocíos y resbalaban en los caminos" (Díaz del Castillo, 1939, t. II, p. 314). Sus habitantes, además, nunca fueron sometidos por los mexicas, aunque sí padecieron por décadas el asedio militar (Barros, 2007, p. 338), por lo que estaban bien ejercitados en la guerra y resultaron fieros oponentes.

Así, luego de que los capitanes Briones y Rodrigo Rangel sufrieran sendas derrotas (Díaz del Castillo, 1939, t. II, pp. 314-315, 404-406), Cortés decidió orquestar un ataque a la región por tres frentes. Aunque el extremeño no tuvo ya tiempo de ejecutar su plan, pues perdió la gobernación de la Nueva España y la capitanía general entre julio y septiembre de 1526, su plan fue seguido por el gobernador Marcos de Aguilar, quien envió a Alonso de Herrera para entrar en la sierra de los zapotecas por el noroeste; a Diego de Figueroa para entrar por el rumbo de Oaxaca, al suroeste; ${ }^{1} \mathrm{y}$ a Gaspar Pacheco, para entrar quizá por la región de Cajonos. Como resultado de estas campañas, en enero de 1527, se fundó la Villa Alta de San Ildefonso, cuya fundación ha sido atribuida tanto a Gaspar Pacheco (Oudijk, 1995, p. 52) como a Diego de Figueroa. ${ }^{2}$

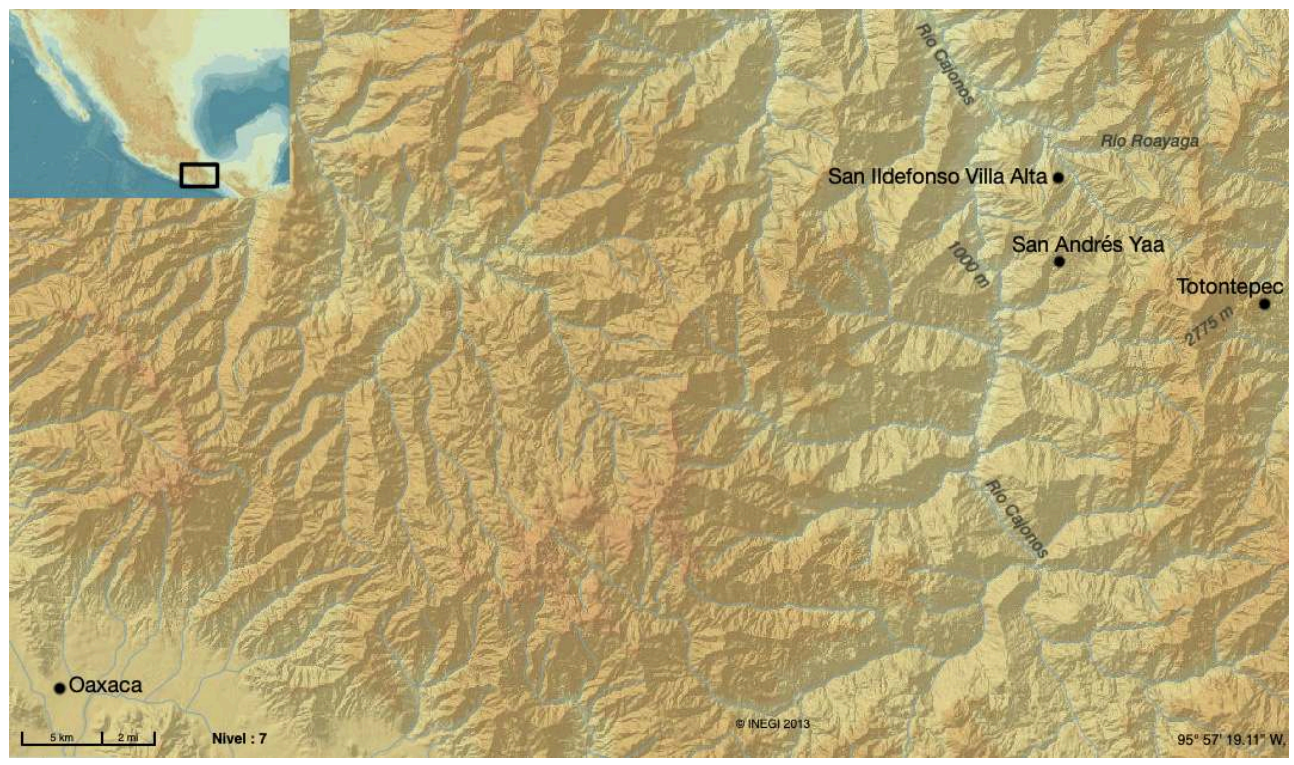

MAPA No 1

San Ildefonso Villa Alta fue fundado en el corazón de las llamadas "sierras de los zapotecas y mixes", 70 km al noreste de la ciudad de Oaxaca. Región montañosa y húmeda descrita por algunos soldados españoles como "la tierra más áspera y fragosa y de muy grandes sierras que hay en toda esta Nueva España". En el mapa se muestran las dos localidades con las que Analco tuvo conflictos por tierras en el periodo colonial. Fuente: elaborado por la autora a partir de http://gaia.inegi.org.mx/mdm6/

Debido a que en la sierra no se podía transitar a caballo, las campañas de conquista se hicieron a pie. ${ }^{3}$ Ello, sumado a las derrotas infligidas por zapotecos y mixes, dificultó el reclutamiento de hombres para las entradas de 1526. Por ello fue de gran importancia 
el auxilio de numerosos "indios amigos", guerreros procedentes del centro de México, ${ }^{4}$ según lo señalaron contemporáneos como Bernal Díaz del Castillo, quien estuvo presente en algunas de estas empresas militares. Los propios mexicanos de Analco dejaron también constancia de su participación en tales procesos: por ejemplo, la documentación generada por el barrio de Analco durante el periodo colonial hace referencia constante a su calidad de "conquistadores de estas provincias". ${ }^{5}$ Más impresionante, sin embargo, fue la elaboración de un testimonio pictórico, que los de Analco mandaron fabricar para dejar en claro su crucial participación en la conquista de la Sierra Norte: se trata del Lienzo de Analco, una pintura realizada en tela de algodón de 3 por 1.8 metros que hoy día resguarda la Biblioteca Nacional de Antropología e Historia, en la Ciudad de México. En él, los mexicanos describieron de forma vívida y detallada su fiel participación en las campañas militares, en el reconocimiento del territorio, en el sometimiento de los señores locales, en las batallas contra zapotecos y mixes, a más de su importancia como aliados y auxiliares en el proceso que siguió a la conquista: el establecimiento de las instituciones castellanas, la implantación de la religión cristiana y el mantenimiento del orden a nivel regional, lo que implicó también prestar auxilio militar para sofocar las numerosas rebeliones que siguieron a la fundación de San Ildefonso Villa Alta.

6 La particularidad de haber sido un pequeño enclave de nahuas rodeados de un gran número de pueblos zapotecos y mixes, a más de su papel como auxiliares de la policía cristiana -característica que los distinguió durante buena parte del periodo colonialha suscitado la atención de diversos historiadores. John K. Chance, en su etnohistoria colonial de la alcaldía mayor de Villa Alta, no dejó de notar la importancia que tuvo este asentamiento de indios aliados en la supervivencia de la precaria villa española de San Ildefonso. Y es que, durante su primer siglo de existencia, los españoles de San Ildefonso se quejaron en forma recurrente de los pocos beneficios que obtenían de sus encomiendas; de la escasez y desabasto de alimentos que sufrían a causa de que los zapotecos y mixes se negaban a entregarles maíz; de la lejanía de otros centros de población española, así como del carácter belicoso y levantisco de los indios locales, patente en las rebeliones y tumultos que cada tanto asolaban la región. En este contexto, señaló Chance, los nahuas de Analco fueron una pieza fundamental para evitar que los españoles abandonaran Villa Alta (Chance, 1998, pp. 54-58).

7 Yanna Yannakakis, por su parte, ha analizado a detalle el rol político y cultural que desempeñaron los indios de Analco en el establecimiento del control colonial en esta lejana región de la Nueva España. Yannakakis pone especial énfasis en el papel de estos nahuas no solo como auxilares armados en las campañas de conquista, sino también como intermediarios entre los españoles y la población nativa de la región en las primeras décadas de existencia de la villa hispana. Para el siglo XVII, además de ayudar a sofocar rebeliones y tumultos, los de Analco fungían también como traductores, mensajeros, ayudaban en el cobro de tributos y en general auxiliaban la impartición de justicia y las labores de los alcaldes mayores. Para el siglo XVIII, en cambio, los mexicanos se vieron sometidos a las presiones por parte de la autoridad hispana para limitar sus privilegios, lo que llevaría, hacia fines del periodo colonial, a una pérdida parcial de sus funciones y, con ello, de sus privilegios (Yannakakis, 2007; 2008). Por mi parte, en una investigación sobre milicias de indios en el territorio novohispano, dediqué un breve apartado a analizar el rol militar de los nahuas de Analco, quienes gozaron durante buena parte del periodo colonial del "privilegio de soldados", en 
virtud del cual estuvieron exentos del pago de tributo, a cambio de dar auxilio armado a los españoles de Villa Alta en caso de necesidad (Güereca, 2016, pp. 51-63).

8 Finalmente, otros investigadores se han visto atraídos a Analco por la belleza y singularidad del ya mencionado lienzo. Es el caso de Viola König (1993), Florine Asselbergs (2004; 2007), Yanna Yannakakis (2011), Pedro Rafael Mena (2019) y Raquel Güereca (2020). Estos trabajos, que combinan el análisis iconográfico con el de fuentes escritas, han dado lugar a una identificación del mensaje contenido en el lienzo, a la ubicación de algunos de los sitios que aparecen en él, así como al desciframiento de algunas de sus escenas.

9 Así, sabemos bastante sobre la vida política de los indios de Analco. No obstante, hay un aspecto que al día de hoy ha sido poco abordado: su historia agraria. Ello se ha debido, por una parte, a que la abundante historiografía sobre la relación entre los pueblos de indios y la tierra en Oaxaca se ha enfocado a otras regiones, como los Valles Centrales y la Mixteca, con una notoria falta de estudios relativos a la Sierra Norte. Por otra parte, nos encontramos también con la aparente ausencia de fuentes documentales sobre este tema. En el Archivo General de la Nación, México, así como en el Archivo General del Estado de Oaxaca y en el Archivo Histórico Judicial de Oaxaca, existe una gran cantidad de documentos relativos a los conflictos por la tierra entre diversos pueblos de indios de la Sierra Norte de Oaxaca, particularmente entre los siglos XVII y XVIII. Sin embargo, pocos de ellos involucran a Analco. Asimismo, si bien sabemos que desde el siglo XVI los indios de Analco recibieron mercedes de tierras para habitar y sembrar, conocemos la ubicación de las primeras, pero no de las segundas. No se conocen tampoco los títulos de tierras del pueblo, y apenas existen algunos testimonios de compra-venta de tierra que involucren a vecinos del barrio de mexicanos. Revisando los trabajos existentes sobre este poblado, da la impresión de que sus habitantes tuvieron escaso vínculo con la tierra, y que la actividad agrícola tuvo poco peso en la economía local, en tanto la mayoría de los indios de Analco se enfocaron en servir a la villa española de San Ildefonso, de donde obtenían buena parte de su sustento. Sin embargo, el conjunto documental del que hablaré a continuación puede contribuir de forma significativa a transformar esta visión.

\section{Los Papeles de Analco: vicisitudes de un patrimonio documental}

Cuando Frans Blom visitó Villa Alta en 1944, se encontró nada más y nada menos que con el Lienzo de Analco. El arqueólogo danés llegó a la Sierra Norte formando parte de una comitiva enviada por el Instituto Nacional Indigenista para estudiar las rutas de migración de la oncocercosis; no obstante, su formación profesional lo llevó a preguntar por los "tesoros" resguardados por los indígenas: "documentos, códices o lienzos de tiempos lejanos" (Blom, 1945, p. 127). Tuvo la suerte de que el presidente municipal de Villa Alta, originario de Analco, accediera a mostrarle los documentos que por siglos habían sido resguardados por la comunidad. Según su propia descripción,

Entraron unos hombres cargando unos bultos envueltos en periódicos viejos; de uno de éstos sacaron un trapo viejo, o al menos así parecía. Varios de los hombres extendieron el "trapo" que resultó ser una maravilla: un lienzo original de los días de la conquista, cubierto en toda su superficie con figuras y pinturas (Blom, 1945, pp. 127-128). 
11 Como el propio Blom señaló, los guardianes del Lienzo de Analco preservaban también otros documentos en papel hispano, a los que se ha prestado poca atención: se trataba, según su descripción, de cinco legajos del siglo XVI fechados entre 1565 y 1589 escritos en castellano, así como un legajo "casi enteramente escrito en náhuatl, con solo unos cuantos folios en castellano", fechado en 1560. A ellos se sumaba un legajo sobre la Cofradía del Santísimo Rosario, que según Blom databa de 1585, así como otros papeles de los siglos XVIII y XIX (Blom, 1945, pp. 128-129).

El Lienzo de Analco fue donado al Museo Nacional de Antropología en 1969 por un particular, ${ }^{6}$ pero la donación no incluía ningún documento. ¿Qué fue entonces de los papeles que menciona Blom? Pocos investigadores, al día de hoy, se han preocupado por su localización, a pesar de su relevancia para conocer la historia de la región en el siglo XVI, periodo del que existe poca documentación; incluso, hay quienes han llegado a decir que se encuentran perdidos. No obstante, como mostraré a continuación, tales documentos han estado siempre en Villa Alta, si bien han sufrido pérdidas considerables en el transcurso del tiempo.

Según sabemos por Blom, los expedientes eran, en su amplia mayoría, litigios por tierras "entre la gente de Analco y los indios mijes y zapotecos, sus vecinos" (Blom, 1945, p. 128), a excepción del ya mencionado legajo de la Cofradía de la Virgen del Rosario. Pasaron treinta años desde que Blom pisó Villa Alta hasta la llegada de John K. Chance, quien se abocó al estudio de la historia colonial de la región, cuyos resultados fueron publicados en inglés en 1989 y traducidos al castellano once años después. Este libro fue el resultado de las diversas estancias en la Sierra Norte que Chance llevó a cabo entre 1975 y 1978. En tales ocasiones, Chance tuvo oportunidad de consultar el Archivo Parroquial de Villa Alta en donde refirió haber hallado, además de los libros parroquiales con registros demográficos de Villa Alta y algunos pueblos cercanos, "un legajo de papeles pertenecientes a las tierras de Analco" (Chance, 1998, p. 299). No obstante, Chance no refiere que tales documentos, a los que cita como Papeles de Analco, hayan sido los mismos que contempló Blom tres décadas atrás.

Un asunto importante es que Chance en ningún momento menciona haber visto entre los Papeles de Analco algún documento escrito en lengua náhuatl. Quizá esto fue lo que le impidió darse cuenta de que se trataba de los mismos documentos referidos por Blom en 1945. Es probable también que a ello se deba la afirmación de Asselbergs referente a que los papeles que vio Blom se habrían perdido (Asselbergs, 2004, p. 236), afirmación repetida después por otros autores (Yannakakis, 2011, p. 622; Rafael, 2019, p. 1).

Sin embargo, durante una visita a San Ildefonso Villa Alta en noviembre de 2019 pude constatar que buena parte de los Papeles de Analco se encuentran aún hoy en el Archivo Parroquial de Villa Alta (en adelante, APVA). Se trata de nueve expedientes que recientemente fueron colocados en carpetas a las que se asignó un número progresivo, aunque se desconoce el criterio. Los expedientes uno y dos están fechados en 1589; el número tres, de 1685, es el libro de la Cofradía del Rosario -cuya fecha Blom leyó como 1585-; el cuarto tiene fecha de 1564 y el quinto de 1567-1589. A estos siguen dos expedientes del siglo XVIII (1717 el sexto y 1767 el séptimo), y uno del siglo XIX (1842). Hay además un "Inventario general de los documentos que obran en el Archivo de la municipalidad del pueblo de Analco" que contiene información de 1824 a 1866. Este último documento no fue colocado en carpeta ni rotulado, pero forma parte del mismo legajo. En total, los nueve documentos suman 258 folios. 
16 Si bien las fechas de los documentos dejan poco margen de duda de que se trata de los papeles vistos por Blom en 1944, un cotejo detallado entre lo referido por el arqueólogo danés y los Papeles de Analco revela otras sorpresas. Y es que Blom transcribió de forma casi literal algunos fragmentos de los documentos. Por ejemplo, refiere que un documento fechado en 9 de agosto de 1589 dice:

se presentó una petición de los indios mexicanos naturales del pueblo de Analco sujeto a esa villa por lo cual hicieron relación que al tiempo que se había ido desde la dicha Ciudad de México en ayuda de los conquistadores españoles que se habían quedado a vivir en ella para ayudar a tener segura la tierra y servir en las demás ocasiones en cuya remuneración mi virrey don Luis de Velasco por el año de 55 había dado un mandamiento etc. (Blom, 1945, p. 128).

17 Este fragmento, sin embargo, no aparece en ninguno de los nueve expedientes del Archivo Parroquial de Villa Alta, que ya he paleografiado y transcrito en su totalidad. Lo mismo sucede con la referencia a un documento del 17 de abril de 1551 que, de acuerdo con Blom, decía:

cuando los conquistadores españoles eligieron a Juan Gómez para representante frente al virrey, se dice que los indios de aquella sierra eran pobres y bulliciosos, indómitos y holgazanes; que jamás habían servido a Moctezuma ni a otro señor de la Tierra; que hacía veinticuatro años que se había fundado la villa (1527), sin faltar en cada uno de ellos alguna rebelión y que en la última que había ocurrido en el año próximo anterior, sin oportuno socorro de Oaxaca, hubieran perecido seguramente los veinte vecinos de San Ildefonso (Villa Alta). (Blom, 1945, p. 130).

18 Entonces, ¿son los Papeles de Analco los mismos que vio Blom en 1944, o no? La respuesta a este cuestionamiento se encuentra en otro repositorio documental: la Family History Library de la Iglesia de Jesucristo de los Santos de los Últimos Días (en adelante, IJSUD), comúnmente conocidos como mormones.

Como es sabido, desde hace décadas la IJSUD se ha ocupado de microfilmar -y más tarde, digitalizar- los documentos de muy diversos archivos: nacionales, estatales, municipales, parroquiales, censos, registros civiles, entre otros. ${ }^{7}$ Ello ha dado lugar a uno de los repositorios digitales más importantes del mundo para los interesados en genealogía y heráldica, y en historia en general. Desde hace unos años, la biblioteca está abierta a la consulta libre para cualquier usuario, sea miembro o no de la Iglesia, a través de su base de datos en línea Family Search. Por poner solo un ejemplo, para el estado de Oaxaca encontramos más de siete millones de imágenes divididas en dos colecciones: "Registro Civil, 1861-2002", con 3.865.729 imágenes, y "Registros parroquiales y diocesanos, 1559-1988", con 3.458 .764 imágenes. Es en esta última colección en la que se ubica el microfilme número 4782319, titulado "Juicios y demandas de límites de tierras de Analco y Tototepeque 1559-1842" procedente de la parroquia de Nuestra Señora de los Remedios y clasificado dentro de los documentos del pueblo de San Juan Evangelista Analco.

20 La clasificación es, evidentemente, equivocada. San Juan Evangelista Analco es actualmente un municipio del distrito de Ixtlán, en la Sierra de Juárez, Oaxaca. Ciento doce kilómetros por una escarpada carretera, y más de cuatro horas de recorrido en auto -si las lluvias o derrumbes no entorpecen el viaje- separan a San Juan Evangelista Analco de San Ildefonso Villa Alta. Este pueblo zapoteco en el periodo colonial estuvo sujeto a Atepec, jurisdicción de Tecocuilco, del que se separó en los primeros años del siglo XVIII para conformarse en una república de indios con derecho a nombrar sus propias autoridades. ${ }^{8}$ Debido a que comparte nombre con el barrio de mexicanos 
establecido a las afueras de Villa Alta, a San Juan Evangelista Analco se le adjudicaron en la base de datos de la Familiy History Library (en adelante, FHL) los documentos que, en realidad, pertenecen a la parroquia de San Ildefonso Villa Alta. ${ }^{9}$ Pero una rápida revisión del microfilme en cuestión señala con claridad, desde la primera imagen, que tales documentos fueron filmados en la parroquia de San Ildefonso Villa Alta el 15 de abril de 1978 por Jesús Pérez. ${ }^{10}$

En el microfilme de la FHL encontramos ocho de los nueve expedientes que aún hoy se conservan en el Archivo Parroquial de Villa Alta. Sin embargo, hay también otros siete documentos que hoy día ya no se localizan en el APVA. La temática general de estos expedientes es la misma: conflictos de tierras con los pueblos vecinos. Cinco están fechados en el siglo XVIII y, de ellos, uno es particularmente relevante pues se trata de un traslado, realizado en 1771, de los documentos probatorios de las exenciones y privilegios obtenidos por los mexicanos de Analco en el siglo XVI, entre los que se incluye el "Asiento, capitulaciones y pactos fechos con los españoles patrimoniales de la Villa Alta" en 1552, ${ }^{11}$ así como una real provisión de Felipe V fechada en 9 de agosto de 1589, documento del que Blom extrajo la primera cita anotada atrás. ${ }^{12}$ Hay también dos expedientes del siglo XIX.

En la siguiente tabla podemos observar de forma sintética el contenido de los 16 expedientes que conforman el legajo de Papeles de Analco. En ella he indicado la temática general que se aborda en cada expediente, la fecha del documento más antiguo y del más reciente, así como el número de las imágenes dentro del microfilme de la FHL. En la última columna, señalo la correspondencia con los expedientes que aún se localizan en el APVA. Vale la pena notar, en las últimas dos columnas, las discrepancias entre los documentos, tal y como fueron microfilmados en 1978, y los que se encuentran en el Archivo Parroquial de Villa Alta en la actualidad. En total, son poco más de 130 folios cuyos originales no están ya en la parroquia y lo único que queda de ellos es la copia que resguarda la FHL. Es decir que, en el curso de las cuatro décadas que han transcurrido desde la filmación al día de hoy, el legajo de Papeles de Analco ha perdido más del 30 por ciento de su volumen documental. No solo eso: la documentación ha perdido también su organización interna, dado que los cinco legajos que consignó Blom, hoy día han sido desarticulados, sin que conozcamos el criterio. 


\begin{tabular}{|c|c|c|c|}
\hline Temática del expediente & Fechas límite & $\begin{array}{l}\text { Microfilme } \\
\text { de la FHL }\end{array}$ & $\begin{array}{l}\text { Papeles de } \\
\text { Analco, APVA }\end{array}$ \\
\hline $\begin{array}{l}\text { I. Los principales y el cumún Jel pueblo } \\
\text { de Analco se querellan en contrat los } \\
\text { principales del pueblo de Totontepeque. } \\
\text { por usurpación de tierras }\end{array}$ & $1555-1591$ & $\begin{array}{l}\text { Imágenes } \\
281 \text { a } 317\end{array}$ & $\begin{array}{l}\text { Expediente } 1.34 \\
\text { folios }\end{array}$ \\
\hline $\begin{array}{l}\text { I. Los princinales de Totontepeque } \\
\text { denuncian ante el alcalde mayor haber } \\
\text { sido desposeídos de casas y sementeras }\end{array}$ & $1555-1589$ & $\begin{array}{l}\text { Imágenes } \\
317 \text { a } 353\end{array}$ & $\begin{array}{l}\text { Expediente 2,38 } \\
\text { folios }\end{array}$ \\
\hline $\begin{array}{l}\text { III. Querellat del pueblo de Analco } \\
\text { contra eld Ye Yayo, por unas tierras que } \\
\text { llaman llaman Caltepeque y Traltenango }\end{array}$ & $1567-1589$ & $\begin{array}{l}\text { Imágenes } \\
353 \text { a } 398 .\end{array}$ & $\begin{array}{l}\text { Expediente } 5.43 \\
\text { folios }\end{array}$ \\
\hline $\begin{array}{l}\text { IV. Documentos varas sobre bicnes de } \\
\text { conunidad y querella con los indios del } \\
\text { barrio de Las Milpas }\end{array}$ & 1564-1593 & $\begin{array}{l}\text { Imágenes } \\
398 \text { a } 410\end{array}$ & $\begin{array}{l}\text { Expediente 4, } 11 \\
\text { folios }\end{array}$ \\
\hline $\begin{array}{l}\text { V. Mandamiento para reconocimiento de } \\
\text { la cruz nmojonera con los de } \\
\text { Totonteneque }\end{array}$ & 1815 & $\begin{array}{l}\text { Imágenes } \\
410 \text { a } 414\end{array}$ & No se localiza \\
\hline $\begin{array}{l}\text { VI. Libro de elecciones, cargos y } \\
\text { descergos de los mayordomos y demás } \\
\text { oficiales de la cofradfil del Santísimo } \\
\text { Rosario de Analco }\end{array}$ & $1685-1779$ & $\begin{array}{l}\text { Imágenes } \\
414 \text { a } 449\end{array}$ & $\begin{array}{l}\text { Expediente 3,23 } \\
\text { folios }\end{array}$ \\
\hline VIII Título de composición de Analco & $1717-1759$ & $\begin{array}{l}\text { Imágenes } \\
450 \text { a } 462\end{array}$ & $\begin{array}{l}\text { Expediente 6, } 14 \\
\text { folios }\end{array}$ \\
\hline $\begin{array}{l}\text { VIII. Acuerdo entre Totontepeque y } \\
\text { Analco sobre las tierras de Tecpanam }\end{array}$ & 1589-1818 & $\begin{array}{l}\text { Imágenes } \\
462 \text { a } 482 \\
\end{array}$ & No se localiza \\
\hline IX. Querella por las tierras de Tecpanam & $1712-1772$ & $\begin{array}{l}\text { Imasenes } \\
482 \text { a } 523\end{array}$ & $\begin{array}{l}\begin{array}{l}\text { Expediente } 7,44 \\
\text { folios }\end{array} \\
\end{array}$ \\
\hline $\begin{array}{l}\text { X. Diversas diligencias promovidas por } \\
\text { Totontepeque contra Analco por mover } \\
\text { mojomeras }\end{array}$ & $1749-1762$ & $\begin{array}{l}\text { Imágenes } \\
523 \text { a } 543\end{array}$ & No se localiza \\
\hline $\begin{array}{l}\text { Xoj. Solicitud de copia de los testimonios } \\
\text { presentados por los de Analco }\end{array}$ & $1549-1771$ & 543 a 558 & No se localiza \\
\hline $\begin{array}{l}\text { XII. Diligencias practicadas a pedimento } \\
\text { del conún del barrio de Analoo sobre } \\
\text { sus tierras de común }\end{array}$ & 1776 & 558 a 567 & No se Iocaliza \\
\hline $\begin{array}{l}\text { XIII. Diligencias practicadas sobre el } \\
\text { desempeño de tierras cue hicieron los } \\
\text { naturales del barrio de Analco a los del } \\
\text { pueblo de San Andrés Yaa }\end{array}$ & $1733-1785$ & 567 a 599 & No se localiza \\
\hline $\begin{array}{l}\text { XIV. Solicitud de copia de los papeles } \\
\text { de sus tierras del comán del pueblo de } \\
\text { Analco }\end{array}$ & 1589-1818 & $600 \mathrm{a} 628$ & No se localiza \\
\hline 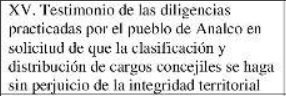 & 1842 & 629 a 650 & $\begin{array}{l}\text { Expediente 8, } 19 \\
\text { folios }\end{array}$ \\
\hline $\begin{array}{l}\text { XVI. Inventario genercal de los } \\
\text { Jocumentos que boran en le Archivo de } \\
\text { la municipalidad del pueblo de Analco }\end{array}$ & 1824-1866 & \begin{tabular}{|l|} 
No se \\
localizat
\end{tabular} & $\begin{array}{l}\begin{array}{l}\text { Expediente } 9,34 \\
\text { folios }\end{array} \\
\text { S }\end{array}$ \\
\hline
\end{tabular}

TABLA No 1. Los Papeles de Analco, en la FHL y en el APVA.

Es importante señalar que varios de los documentos contenidos en el legajo fueron copiados en diferentes épocas, por lo que se pueden encontrar duplicados o, incluso, triplicados. Es el caso de la "Merced de tierras dada por el virrey Luis de Velasco a los naborías", signada en la Ciudad de México el 9 de abril de 1555, cuyo original se ubica en el expediente II, pero fue copiada en los años 1589 y 1591; ambas copias forman parte del expediente I. Lo mismo ocurre con el testimonio de la entrega de las tierras mercedadas llevada a cabo por el juez de residencia Marcos Ruiz de Rojas el 10 de junio de 1555, y la confirmación de las tierras por el virrey Luis de Velasco, dada en la Ciudad de México el 14 de agosto de 1555.

En el mismo sentido, el contenido de los expedientes VIII y XIV es prácticamente el mismo, e incluye copias de los siguientes documentos: 1) la real provisión de Felipe $\mathrm{V}$, dada en la Ciudad de México el 9 de agosto de 1589; 2) un mandamiento del virrey Luis de Velasco para que se guarde el concierto hecho entre Totontepeque y Analco, sobre mojoneras, dado en la Ciudad de México el 3 de marzo de 1592; 3) el testimonio de haberse dividido las tierras en litigio entre Analco y Totontepeque con acuerdo y en presencia de ambos pueblos, el 14 de noviembre de 1592;4) una denuncia interpuesta por los indios de Analco ante el alcalde mayor de Villa Alta contra los indios de Totontepeque, por no respetar el acuerdo de 1592, hecha el 3 de abril de 1601; y 5) un testimonio de la vista de ojos de las tierras en disputa entre ambos pueblos, y la orden del alcalde mayor de dividirla a partes iguales, del 6 de abril de 1601. El hecho de que tales documentos hayan sido copiados en diversas ocasiones y presentados como pruebas en los litigios de tierras, nos habla de la importancia que revistieron para el pueblo de Analco. Por ello, la selección que he decidido publicar aquí corresponde a tales documentos, específicamente, al expediente XI de la tabla. 

historia de Analco, quisiera llamar la atención sobre dos asuntos. El primero es que cuando Frans Blom vio estos documentos en 1944, todavía se encontraban en "la casa que antes había sido ayuntamiento del pueblo libre de Analco" (Blom, 1945, p. 129) ubicada en el barrio del mismo nombre, mientras que en 1978, el legajo de Papeles de Analco había pasado ya a formar parte del acervo de la parroquia de Villa Alta, donde fue microfilmado. Todo parece indicar que 1944 fue un año clave en la historia del antiguo asentamiento de mexicanos, pues fue en esa fecha que perdió su calidad de pueblo independiente para convertirse en un barrio subordinado a Villa Alta. Es posible que este hecho diera lugar a una rápida pérdida de la identidad local y al desmembramiento de lo que quedaba de los lazos comunitarios. Sin embargo, hace falta indagar entre los habitantes de la actual localidad de Villa Alta y su barrio Analco qué ocurrió en esos años. Un acercamiento de carácter antropológico podrá dar luz sobre lo que seguramente fue un complejo proceso político y social.

Lo que es innegable es que, en el curso de los treinta años siguientes, el acervo que resguardaban las autoridades de Analco se desarticuló. Por un lado, los papeles que habían servido durante siglos para defender sus tierras pasaron a la parroquia de Villa Alta. En ese mismo periodo, además, el Lienzo de Analco salió del pueblo, sin que tengamos la certeza de si fue vendido, sustraído ilegalmente (Asselbergs, 2004, p. 295) o "rescatado" según la versión de su donante al Museo Nacional de Antropología en 1969. ${ }^{13}$ Es posible que el documento en náhuatl que vio Blom se haya perdido también por esos años, dado que en el microfilme de la FHL, lamentablemente, no se encuentra documento alguno en lengua indígena. Pero no es el único documento faltante: tampoco se encuentra el segundo documento citado por Blom, fechado en 17 de abril de 1551, y que refiere el nulo sometimiento de mixes y zapotecos a Moctezuma. ¿Cuánto más de la documentación que resguardaban los habitantes de Analco se perdió antes de ser microfilmada en 1978? Es imposible saberlo, dada la falta de registros. No obstante, es evidente que la documentación faltante en el microfilme de la FHL es de la mayor relevancia: por un lado, el que pudo ser el documento más antiguo del legajo y, por otro, el texto en lengua indígena. Ello puede ser indicativo no de una pérdida o destrucción de la documentación, sino de una sustracción deliberada de los valiosos materiales.

El segundo asunto sobre el que quiero llamar la atención es que, según los registros de la Family History Library, el documento más antiguo para la diócesis de Oaxaca que la IJSUD ha microfilmado data de 1559. Ese documento no es otro que el legajo de Papeles de Analco, cuyas fechas límite asignadas en la base de datos son 1559-1842. Revisando la base de datos para Oaxaca, que incluye la documentación microfilmada de 227 parroquias ubicadas en 219 localidades, no existe un documento más antiguo. De hecho, solo en cinco archivos parroquiales oaxaqueños se han localizado materiales del siglo XVI. ${ }^{14}$ Más aún: el documento más antiguo dentro de los Papeles de Analco no data de 1559, sino de cuatro años atrás: se trata de la confirmación de tierras dada por el virrey don Luis de Velasco a los indios de Analco en la ciudad de México el 14 de agosto de 1555, cuyo original, con la correspondiente firma autógrafa del virrey, se localiza en el expediente 2, folio 20. Este documento, por suerte, se encuentra aún en el Archivo Parroquial de Villa Alta. Valgan estas líneas para llamar la atención sobre la importancia de resguardar estos materiales de forma adecuada.

Corpus, Vol. 10, №. 2 | 2020 


\section{Lengua, escritura e identidad a través de los Papeles de Analco}

Como ya he dicho, los dieciséis expedientes que conforman los Papeles de Analco giran en torno a dos asuntos: el conflicto por la tierra que sostuvieron con sus vecinos mixes de Totontepec -y en menor medida, con los zapotecos de Yaa-, así como la salvaguardia de los privilegios ganados por su servicio a los españoles durante la conquista. Ambos tópicos van de la mano, pues la tierra les fue otorgada por sus servicios durante la conquista de la Sierra Norte y, para mantenerla y acrecentarla, de forma recurrente presentaron ante las autoridades virreinales la documentación que probaba su estatus privilegiado, que les fue confirmado en numerosas ocasiones.

Por supuesto, a través de estos expedientes es posible reconstruir la historia agraria de Analco, lo cual implica identificar las tierras que les fueron dadas en merced -y que no se ubicaron, como hasta ahora se ha creído, contiguas al barrio, sino a un par de leguas de distancia-; la manera en la que fueron explotadas a lo largo de los siglos, las estrategias empleadas por Analco para acrecentarlas y, ante todo, el largo conflicto que sostuvieron con los mixes de Totontepec con quienes colindaban. Esta documentación nos muestra que los indios de Analco, a pesar de que vivieron sirviendo a la villa española de San Ildefonso, desarrollaron también estrecho vínculo con la tierra. Podemos ver aquí la existencia de una economía mixta en Analco, en la que una parte del sustento se obtenía de los sueldos devengados por los servicios dados a Villa Alta (como ministros, mensajeros, maestros de escuela), mientras que la otra derivaba de la explotación de las tierras mercedadas. Sin embargo, aquí quisiera hablar no de la historia agraria del pueblo -asunto del que me ocuparé en futuros textos-, sino de la forma en que los Papeles de Analco dialogan con otros documentos y con lo dicho ya por otros investigadores, ya sea confirmando o refutando sus aseveraciones.

Es importante notar que, al día de hoy, no contamos con un solo documento en náhuatl escrito por los mexicanos de Analco. Existen, sí, cerca de 80 documentos en dicha lengua procedentes de la Sierra Norte de Oaxaca, resguardados en la actualidad por el Archivo Histórico Judicial de Oaxaca (en adelante, AHJO), en la sección Villa Alta, ramos Civil y Criminal. De acuerdo con Lisa Sousa, estos documentos van de 1572 a 1774 y proceden en su mayor parte de diez pueblos de habla mixe, a saber: Amatepec, Ayutla, Metepec, Ocotepec, Temascalapa, Tiltepec, Tlahuilotepec, Totontepec, Xareta y Xayacastepec. Unos pocos fueron elaborados en pueblos de habla zapoteca, pero ninguno de ellos proviene del barrio de Analco (Sousa, 2017, pp. 46-47).

En este contexto, resulta relevante consignar la poca información que tenemos del texto en náhuatl que formaba parte de los Papeles de Analco, hoy perdido. Según Frans Blom, estaba fechado en 1560 e iniciaba con la frase, escrita en mayúsculas: "ONTITLACUILLOQUE CEPOHUALO O NAHUI TONATIUH Y PA MEZTLI DEZIEBRE AÑOS CAICAN MOTACI MANI". ${ }^{15}$ Entre los firmantes figuraba el dominico fray Pedro de Barahona "el hijo fraile de Don Francisco de Barahona, uno de los más crueles capitanes de Pedro de Alvarado en la conquista de Guatemala" (Blom, 1945, p. 129).

Más allá de la pérdida de este texto, llama la atención el hecho de que, en los casi 400 folios que conforman los Papeles de Analco, no figure ningún otro documento en lengua náhuatl, como tampoco en otros repositorios documentales. Este hecho resulta extraño si tomamos en cuenta que buena parte de la documentación contenida en los Papeles de 
Analco data del siglo XVI y que, por esas mismas fechas, otros nahuas que auxiliaron las conquistas, o sus descendientes, se hallaban escribiendo profusas relaciones en su lengua nativa, como ocurrió con los mexicanos en Guatemala (Dakin y Lutz, 1996). Caso paradigmático es el de los tlaxcaltecas establecidos en 1591 junto a la villa de Saltillo, en el noreste de la Nueva España, ${ }^{16}$ quienes continuaron escribiendo en náhuatl testamentos, acuerdos de compra-venta, peticiones al virrey, actas de cabildo, entre otros- hasta bien entrado el siglo XVIII (Celestino, 1991). Dado que, como hemos visto, una parte significativa de los documentos elaborados por los mexicanos de Analco se ha perdido, es posible que existieran otros documentos en náhuatl elaborados en dicho pueblo, que no resistieron el paso del tiempo. Sin embargo, no deja de llamar la atención que el propio Blom señaló haber visto un solo legajo en náhuatl dentro del conjunto de Papeles de Analco.

Dado que ni los Papeles de Analco, que consignaban buena parte de la memoria sobre las tierras y privilegios de la comunidad, ni otros archivos -como el Archivo General de la Nación, el Archivo General de Indias, el Archivo Histórico del Estado de Oaxaca o el ya mencionado Archivo Histórico Judicial de Oaxaca- consignan la existencia de documentos en náhuatl escritos por los de Analco, todo apunta a que escribieron poco en su lengua. No solo eso: pareciera que, en fecha bastante temprana, los indios de Analco se comunicaban mayormente en castellano. Así, ya para 1592 el alcalde mayor de Villa Alta señalaba que la mayor parte de los de Analco eran "ladinos en lengua castellana", ${ }^{17}$ afirmación sustentada también por sus vecinos mixes de Totontepec en fecha cercana. ${ }^{18} \mathrm{~A}$ partir del siglo XVII, en buena parte de sus interacciones con la autoridad hispana, los de Analco se comunicaban en castellano, a diferencia de los pueblos mixes y zapotecos, en donde los principales y algunos intermediarios dominaban el castellano, mientras que los indios del común requerían, la mayor parte de las veces, de un traductor. Los de Analco en ocasiones fungieron como intérpretes, e incluso, como maestros de castellano, pues gracias a que contrajeron matrimonio con mujeres locales aprendieron también el zapoteco (Yannakakis, 2007, pp. 240, 246). Estas, entre otras habilidades, les permitieron fungir como intermediarios entre los pueblos de indios serranos y los españoles (Chance, 1998, p. 62).

Sin duda, hace falta un estudio mucho más puntual del tema. Lo cierto es que existen otros casos de nahuahablantes que fungieron como aliados de la colonización española y fueron los primeros en abrazar el castellano. Tal fue el caso de los tlaxcaltecas que arribaron a Colotlán, en el norte de Jalisco, en 1591. En ese caso, la pequeña colonia de nahuahablantes, rodeados de numerosos pueblos de huicholes, zacatecos, tepecanos y coras, adoptó muy pronto el castellano como una forma de reforzar su cercanía y asociación con las autoridades hispanas. A pesar de que la documentación de esta región es fragmentaria y mucho de ella se perdió, se han podido conservar algunos documentos escritos en náhuatl por coras y huicholes, mientras que de los tlaxcaltecas de Colotlán se ha localizado solo un texto: se trata de la traducción al náhuatl de un mandamiento virreinal, elaborado en el temprano siglo XVIII. Aunque en algunos casos huicholes, coras y tepecanos emplearon traductores para escribir sus documentos, sabemos también que algunos individuos -principales, caciques- hablaban náhuatl y aprendieron a escribirlo. En cambio, los tlaxcaltecas de Colotlán hablaban y escribían en castellano, y convirtieron esta habilidad en signo de su calidad de cristianos viejos y leales vasallos del monarca. Ello no implica que hayan abandonado el uso del náhuatl en el ámbito doméstico o intracomunitario, pero sí produjo una escasez de documentos en su lengua nativa (Güereca, 2018, pp. 454-451), comparable con lo que ocurrió con los 
mexicanos de Analco, cuya identificación con la cultura y lengua española los llevó, posiblemente, a privilegiar el uso del castellano en sus interacciones con la autoridad hispana.

Una de las interrogantes respecto a los indios de Analco tiene que ver justamente con su identidad étnica, debido a que, en la documentación, y particularmente en el Lienzo de Analco, nunca señalan cuál era su lugar de origen antes de migrar a la Sierra Norte, como sí hicieron tlaxcaltecas y quauhquecholtecas al elaborar sendos lienzos para conmemorar su papel como aliados de las conquistas. De tal suerte, y basado en la memoria oral de los habitantes del barrio, Blom consignó en 1945 que la Sierra Norte habría sido conquistada por tlaxcaltecas aliados de los españoles (Blom, 1954, p. 135). Chance, por su parte, si bien remarcó que se trataba de naborías hablantes de náhuatl originarios de diversos pueblos del centro de México, afirmó que eran mayoritariamente tlaxcaltecas (Chance, 1998, p. 62). Tanto König como Asselbergs sustentan la afirmación del origen tlaxcalteca de los indios de Analco, e incluso señalan el "estilo tlaxcalteca" del lienzo elaborado en el siglo XVI. No obstante, Yannakakis hizo notar ya hace algunos años que las referencias a Tlaxcala como lugar de origen de estos indios son escasas y no aparecen en la documentación que ella consultó sino hasta el año de 1761 (Yannakakis, 2007, p. 237), mientras que en la documentación de los siglos precedentes los de Analco eran referidos como naborías o mexicanos.

La misma Yannakakis ha mostrado la imprecisión que revisten ambos términos: en el caso de naborías, podía hacer referencia tanto a indios de servicio doméstico o criados, que servían a los españoles también como trabajadores del campo, artesanos y auxiliares militares en caso necesario. Para fines del siglo XVI, el término comenzó a asociarse con los trabajadores urbanos, indios migrantes, desarraigados de sus comunidades de origen que se asentaban en las ciudades de españoles, o en sus alrededores, y se dedicaban a proveer de bienes y servicios a la sociedad colonial urbana, trabajando como artesanos, sirvientes domésticos y trabajadores agrícolas (Yannakakis, 2011, p. 657; Chance, 1976, p. 610). Mexicanos, por su parte, es un término que en el siglo XVI se empleaba comúnmente para referir a los hablantes de náhuatl o "lengua mexicana" procedentes de comunidades diversas del centro de México y, en el caso particular de Oaxaca, a los hablantes de náhuatl establecidos en los valles centrales y en el istmo de Tehuantepec (Yannakakis, 2007, p. 236). Chance, además, registra otro uso del término: en Jalatlaco, barrio de indios naborías ubicado en las afueras de la villa española de Antequera, mexicano era el término empleado para referir a los hablantes de náhuatl procedentes de Tenochtitlan, pues en Jalatlaco habitaban también nahuas procedentes de otros pueblos, como fueron Tlaltelolco, Tlaxcala o Huejotzingo (Chance, 1976, p. 611).

¿Qué nos dicen los Papeles de Analco respecto a este asunto? En primer lugar, vale la pena resaltar el hecho de que en ninguno de los documentos que forman parte del legajo se hace referencia a un origen tlaxcalteca. Tlaxcala ni siquiera aparece mencionada en los documentos tardíos de los siglos XVIII y XIX. Las únicas evidencias sobre el origen tlaxcalteca de los de Analco que tenemos al día de hoy se limitan entonces a un documento de 1761 en el que algunos habitantes de Analco afirmaron ser "del origen de los primeros tlaxcaltecas auxiliares de los primeros conquistadores de estas provincias"19, la información dada por los habitantes de Analco en 1944 y las afirmaciones de König y Asselbergs respecto al "estilo tlaxcalteca" del Lienzo de Analco. Sin embargo, hay que decir que, tanto en 1761 como en 1944, los habitantes de Analco 
se enfrentaban a intentos por minar su estatus privilegiado: en 1761, el alcalde mayor de Villa Alta ordenó que los soldados que patrullaban por la villa española durante la noche patrullaran también en el barrio indio, hecho que fue leído como un ataque a la autonomía política de Analco. En 1944, en cambio, derivado de un drástico descenso de la población, por órdenes del gobierno estatal, Analco dejó de ser reconocido como "municipio libre" para incorporarse como un barrio subordinado políticamente a Villa Alta (Blom, 1945, p. 135). Así, es posible que, tras los ataques de 1761, ciertos indios de Analco hayan recurrido a identificarse como tlaxcaltecas - una bien conocida identidad de prestigio- como un medio para detener los intentos de las autoridades locales por desconocer su estatus. Con el paso del tiempo, esta afirmación respecto al origen tlaxcalteca (que no se sustenta en la documentación conocida hasta ahora) se incorporó a la memoria histórica de la comunidad, perdurando hasta el siglo XX. Y, respecto a la afirmación del "estilo tlaxcalteca" del Lienzo de Analco, baste señalar que, en realidad, se trata de un "estilo nahua" en tanto buena parte de las convenciones pictóricas en el lienzo son compartidas con otros documentos del centro de México de origen nahua y no solo tlaxcalteca, a más de que no que existe una referencia clara a Tlaxcala en dicho lienzo. ${ }^{20}$ Ser tlaxcalteca fue, ya desde los tiempos de las campañas cortesianas, una identidad de prestigio, sinónimo de aliado, de indio conquistador, de buen y leal vasallo, con un estatus y privilegios que los diferenciaban del resto de la población nativa. Parece casi imposible pensar que, de haber habido tlaxcaltecas entre los habitantes de Analco, no hayan dejado constancia de ello, particularmente al momento de acudir ante las autoridades virreinales a solicitar exenciones y privilegios. De tal suerte, es posible afirmar que la presencia tlaxcalteca en la conquista y temprana colonización de la Sierra Norte, si es que la hubo, fue mínima.

En los Papeles de Analco no aparecen tampoco noticias sobre el lugar de origen de los indios del barrio, salvo la referencia, ya citada antes, a que salieron desde la Ciudad de México a ayudar en las campañas de conquista de la sierra. $Y$ aunque es tentador identificar a los de Analco con tenochcas (tomando en cuenta también que mexicanos era usado para referir a los indios de Tenochtitlan en el cercano Jalatlaco), lo cierto es que no es una evidencia contundente, en tanto pudo tratarse de indios nahuas llevados a la Ciudad de México antes de partir a las campañas.

A lo largo de la documentación, los indios de Analco se refieren a sí mismos como naborías o mexicanos, y de esta misma manera son reconocidos tanto por los españoles como por los indios de otros pueblos. No obstante, vale la pena hacer algunas precisiones, pues ambos términos no se usan de forma indistinta. Por una parte, naborías es la expresión más común en la documentación más temprana: por ejemplo, en el acuerdo hecho en Villa Alta para que se les dieran tierras para habitar en 1552, los españoles se refieren a ellos solo como naborías, lo mismo que en la confirmación hecha por el virrey en el mismo año, ${ }^{21} \mathrm{y}$ en la merced de tierras para sembrar, dada en $1555 .^{22}$ Esto concuerda con las evidencias procedentes de otros documentos. Así, en el juicio de residencia al primer alcalde mayor de la región, en 1530, se hace constante referencia a los indios naborías, sin que aparezca en ningún momento el término mexicanos, ${ }^{23}$ que también está ausente en las informaciones de los conquistadores y primeros pobladores de San Ildefonso Villa Alta. ${ }^{24}$ Los mixes de Totontepec y algunos zapotecos lo emplearon también para aludir a los habitantes de Analco, pero los propios indios de Analco solo lo usan en una ocasión: en 1575, para referir "los servicios y trabajos que habíamos pasado con los vecinos de esta dicha ciudad en la pacificación de estas provincias como sus naborías que habíamos sido", ${ }^{25}$ es decir, para señalar que 
lo fueron en el pasado. Naborías aparece por última vez en boca de los mixes de Totontepec en 1589 y está ausente en los escritos de los siglos siguientes.

El término mexicanos, en cambio, aparece por primera vez en 1555 en boca de los zapotecos cajonos de los pueblos de Yaguice, Nestepeque y Yaha, quienes se refieren a los de Analco como "mexicanos y naborías". El virrey también los nombra como mexicanos en 1567, y a partir de 1589 es el término que predomina en la documentación, empleado tanto por los propios habitantes de Analco, como por las autoridades españolas y por otros pueblos de indios. Curioso es notar, por último, que el apelativo de "conquistadores" para referirse a los indios de Analco no aparece en el legajo sino hasta 1717, en el que ellos mismos aluden a todos los habitantes de ese barrio como "mexicanos nobles conquistadores". ${ }^{26}$

En suma, a partir del siglo XVII, las diversas identidades nahuas que posiblemente confluyeron en el barrio de Analco se uniformaron bajo el término genérico de mexicanos, ampliamente aceptado, que carecía además de la connotación de servidumbre que acompañaba al término naboría. No obstante, en los Papeles de Analco podemos ver que a Analco llegaron desde fecha bastante temprana indios no hablantes de náhuatl que, no obstante, fueron incorporados y se denominaron mexicanos. Ya Chance (1998) había especulado que, dado que la mayoría de auxiliares nahuas de la conquista eran varones, una vez establecidos en la Sierra Norte seguramente contrajeron matrimonio con mujeres locales, lo que nutrió el asentamiento nahua con la presencia de mujeres zapotecas. Por los Papeles de Analco, además, sabemos que por lo menos desde 1563 -y posiblemente antes- existía dentro de Analco una parcialidad de zapotecos denominada "Elotepeque" en náhuatl o "Las milpas" en castellano, quienes tuvieron cierta independencia política -en tanto podían nombrar un alguacil mayor-, pero la perdieron en la década de 1570, quedando sujetos a partir de entonces a los mexicanos. Para 1593 aún se menciona a esta parcialidad de zapotecos, pero desaparecen de la documentación, señal de que quizá fueron absorbidos por los mexicanos. Y es que los propios indios de Analco explicaron en 1575 que la migración de indios zapotecas a su pueblo no era infrecuente debido a que sus habitantes gozaban de exención del pago de tributo, por lo que:

algunos indios zapotecas de pueblos comarcanos a esta dicha ciudad ansí de los que están de la real corona como de pueblos de encomienda por gozar de la dicha merced e por ser indios haraganes e vagamundos e no quieren tributar se han venido a poblar junto al dicho pueblo. ${ }^{27}$

Ello explica que, en 1589, los mixes de Totontepec se refirieran a los de Analco como "los indios que dicen son mexicanos", ${ }^{28}$ expresando su reserva respecto a la identidad asumida por el barrio. Y es que, en su larga disputa por la tierra con los de Analco, los mixes tenían muy claro que buena parte de las disposiciones y sentencias favorables obtenidas por los indios de Analco se basaban en ostentar su identidad como mexicanos y descendientes de conquistadores; de ahí que, entre sus argumentos, figuró en varias ocasiones la descalificación de los mexicanos, a los que acusaron de detentar privilegios y exenciones que no les correspondían en tanto no eran descendientes de aquellos indios que llegaron a la Sierra Norte como auxiliares de la conquista. ${ }^{29}$

Así, a través de los Papeles de Analco es posible ver cómo estos indios crecen en poder y prestigio. En los documentos más antiguos figuran como humildes naborías, indios que auxiliaron la conquista por estar al servicio de los españoles, pero nunca como aliados, a quienes los españoles de Villa Alta les otorgaron tierras para habitar debido a la 
"intercesión y por complacer al dicho padre fray Bernardo [de Alcántara]", ${ }^{30}$ a la sazón predicador de la Orden de Santo Domingo en Villa Alta. Los de Analco ni siquiera figuran en el "Asiento y capitulación" firmado en 1552, tratados como hijos menores que requieren de un mentor, el fraile, para negociar.

No obstante, luego de un trabajo sistemático de obtención y confirmación de beneficios y privilegios, los indios de Analco acrecentaron su poder y presencia en la región y, con ello, su margen de acción política. Entre las mercedes recibidas se encuentran la donación de tierras por parte del cabildo español, no para habitar sino para que los de Analco pudieran sembrar. Más adelante, el virrey los libraría del pago de tributo, y sabemos, por documentación de otros acervos, que obtuvieron también el privilegio de portar armas, a más de que se convirtieron en "ministros" y auxiliares de la autoridad hispana, lo que los llevó a ser temidos, respetados y, también, repudiados por otros pueblos de la jurisdicción. En este proceso, abandonaron el apelativo de "naborías" con su connotación de servidumbre para asumirse colectivamente como mexicanos, y más tarde, construirse a sí mismos como "nobles mexicanos conquistadores".

\section{Fuentes}

Archivo General de Indias, sección Justicia, legajo 291; sección México, legajo 203, números 24 y 26; legajo 208, números 8 y 24; sección Patronato, legajo 20, número 5 , R. 1; legajo 72, R. 4; legajo 73, número 1, R. 4; legajo 76, número 6, R. 12; legajo 84 , número 2, R. 2; y sección Guatemala, legajo 110, número 8.

Archivo Histórico Judicial de Oaxaca, sección Villa Alta, serie Civil, legajo 2, expediente 10; legajo 17, expediente 17; legajo 21, expediente 25.

Archivo Parroquial de Villa Alta, sección Papeles de Analco, expedientes 1, 2, 4, 6.

Iglesia de Jesucristo de los Santos de los Últimos Días, Familiy History Library, Mexico, Oaxaca, Church Records, microfilme 004782319.

Asselbergs, F. (2004). Conquered Conquistadors. The Lienzo de Quauhquechollan: A Nahua Vision of the Conquest of Guatemala. Leiden: CNWS Publications.

Asselbergs, F. (2007). The Conquest in Images. Stories of Tlaxcalteca and Quauhquecholteca Conquistadors. En L. E. Matthew, y M. R. Oudijk, (Eds.), Indian Conquistadors. Indigenous Allies in the Conquest of Mesoamerica, (pp. 65-101). Oklahoma: Universidad de Oklahoma.

Transcripción de la selección documental

Referencia: Expediente XI (ver tabla 1), Solicitud de copia de los testimonios presentados por los de Analco, 1549-1771, IJSUD, FHL, Mexico, Oaxaca, Church Records, microfilme 004782319, imágenes 543-558. A efectos de facilitar la lectura, se ha modernizado la ortografía.

[F. 1] No. 13

[Sello] Sello cuarto, un cuartillo, años de mil setecientos y setenta, y setenta y uno

La república y naturales del barrio de Nuestra Señora del Rosario Analco suburbio de esta villa de San Ildefonso [roto] por sí y en nombre del demás común y [roto] por quienes prestamos voz y caución en la [roto] necesaria permisas las solemnidades de [roto] ante vuestra señoría parecemos y decimos que [roto] están formados unos autos que [roto] seguimos con el común y naturales del pueblo de Totontepeque en cuyo motivo nos conviene este ocurso para que vuestra señoría se sirva de mandar un asiento y capitulaciones fechos con los españoles patrimoniales que fueron de esta villa con nueve fojas útiles y dos blancas, que con la debida solemnidad presentamos ante vuestra señoría para que en vista de ellos vea lo mal [roto] alla y que sea hecho 
testimonio con [roto] de dicha república de Totontepeque no nese [roto estos instrumentos para alegar [roto] dicho por tanto

A vuestra señoría pedimos [roto] hacer según llevamos pedido, juramos [roto]

Gerónimo Solano alcalde

[Roto] Olivera

[F. 1v]Villa Alta de San Ildefonso a [roto] días días [sic] del mes de noviembre de 1771 años ante el señor Sancho Pizón y Moya teniente coronel de infantería, alcalde mayor por su majestad de Villa Alta y sus agregados de Guaspaltepec y Tecech[roto] se presentó este escrito [roto] que refiere.

Y por su merced visto lo hubo por p[roto] dichos instrumentos, y en atención [roto] él se relaciona debía mandar y mandó al presente escribano que se halla en esta [roto] la práctica de ciertas diligencias se de a lo [roto] tes el testimonio que de dichos instrumentos [roto] autorizado en pública forma y manera [roto] fe con precedente citación de la república [roto] Totontepeque a que [roto] para este efecto se librará el correspondiente mandamiento de compa[roto] do y por este [roto] así lo proveyó, mandó y firmó

Don Sancho P [roto] [rúbrica]

Ante mí Joseph de Huidobro escribano real y receptor [rúbrica]

Incontinenti se libró el mandamiento prevenido en el auto que antecede y para que conste [roto] esta razón que rubriqué [rúbrica]

[Roto] Ildefonso a diez y nueve días [f. 2] del mes de [roto] de mil setecientos setenta y un años yo es escribano real y receptor teniendo presentes a Felipe Amaya y Joseph Vázquez alcaldes, a Juan Gerónimo [roto] a Pedro Martínez, Andrés Gómez y Antonio Cano principales, a Juan Miguel escribano y a Juan Antonio Vásquez apoderado de la república del pueblo de Santa María Asunción Totontepeque de esta jurisdicción sin necesidad de intérprete por hablar y entender el idioma castellano, les cité en forma con el auto que antecede, y de su efecto entendidos, dijeron que lo oyen, y se dan por citados: esta fue su respuesta de que doy fe. Y lo firmé con los que supieron.

Andrés Gómes [rúbrica] Juan Miguel escribano [rúbrica]

Juan Antonio Vázquez apoderado [rúbrica] Ante mí Joseph de Huidobro escribano real y receptor [rúbrica]

Yo don Antonio de Mendoza visorrey y gobernador por su majestad en esta Nueva España os hago saber a vos el que es o fuere alcalde mayor de la villa de San Ildefonso provincia de los Zaapotlecas [sic] que los indios que se dicen de Capotlan que dicen residen en esa dicha villa fueron a ella cuando aquella provincia se conquistó, me hicieron relación que los vecinos de esa dicha villa por fuerza y contra su voluntad los tienen en sus casas y se sirven de ellos [roto] e hijos [f. 2v] en todos los servicios de sus casas como si fuesen esclavos y los envían con sus cartas a muchas partes lejos de la dicha villa, sin se lo pagar [roto] de todo lo cual han recibido y reciben agravio y daño y en detenerlos en dicha villa sin les dejar gozar de su libertad como personas libres y me pidieron que les de licencia para que los dejasen ir a vivir a donde quisiesen a ellos y a las dichas sus mujeres e hijos. Y por mi visto lo susodicho, mandé dar este mi mandamiento por el cual vos mando que veáis lo susodicho y acerca de ello brevemente hagáis a los dichos indios justicia y pagar luego los servicios que a los vecinos de la dicha villa les hubieren fecho y de aquí en adelante mando que ninguna ni algunas personas de cualesquier calidad y condición que sean, sean osados de tomar ni tener que [roto] de indios libres contra [roto] fuerza y como personas [roto] ir do quisieren [f. 3] y por bien tuvieren y que no los apremien a que por fuerza vayan a llevar cartas ni otras cosas a parte ninguna si no fuere de su voluntad, y pagándoles a los mismos 
su trabajo so pena de cincuenta pesos de oro para la cámara de su majestad a más de que serán castigados conforme a justicia. Fecho en México a 13 días del mes de octubre de 1549 años. [Entre renglones: Don Antonio] Por mandado de su excelencia. Santiago de Jurado.

Asiento, capitulaciones y pactos fechos con los españoles patrimoniales de la Villa Alta

En esta villa de San Ildefonso de la Provincia de los Zaapottecas de esta Nueva España a 15 días del mes de febrero del señor de 1552 años, estando los muy magníficos señores justicia y regidores de la dicha villa en su cabildo y [f. 3v] ayuntamiento según y como lo han de costumbre y por ante mí Juan Manzano escribano nombrado y del concejo de la dicha villa y en presencia del muy reverendo padre fray Bernardo de Alcántara predicador del monasterio del señor Santo Domingo de esta dicha villa, y a intercesión y por complacer al dicho padre fray Bernardo, dijeron los señores justicia y regidores que por bien y es su voluntad de les dar un sitio por donde puedan poblar las naborías que están en esta dicha villa y otras que de otras partes se quisieren venir en términos de esta dicha villa que por la parte del poniente de la otra parte de la quebrada que baja por la caballería de Álvaro Montaño, y por las espalda de la casa de Juan Martínez y del Mo [f. 4] nasterio del señor Santo Domingo, y por las espaldas de las casas de Fernando al_ [sic] ${ }^{31} \mathrm{y}$ pasada la dicha quebrada como dicho es, la cual se les dio por sitio y mojón, y por el cabo de arriba del dicho sitio que hacia el sur linde una caballería de Bartolomé de Contreras, y por la otra parte del poniente con caballería de los menores hijos de Antonio Miguel los cuales dichos mojones como dicho es dijeron que señalaban y señalaron por sitio a donde puedan poblar y estar y hacer casas las naborías como dicho es, de cual dicho sitio dijeron que le _bien [sic], y merced, para agora y por siempre_ [sic]A nombre de su majestad, para que a cada uno de ellos el sitio y solar que le cupiere y le fuere repartido, sea para él y para sus hijos y sucesores de lo cual dijeron que como [f. 4v] dicho tienen les hacían bien y merced, guardando ante todas cosas las ordenanzas siguientes: Primeramente, que las dichas naborías que ahora y de aquí en adelante se poblaren en este dicho sitio sean sujetas y estén al fuero y jurisdicción de la justicia de esta dicha villa como obligado de ella. Otro si, que las dichas naboría que ansí poblaren en dicho sitio no sean osados a sacar ni tomar ninguna agua, por fuera de donde las aguas van y suelen ir, y que si alguna vez quisieren sacarla para las que se han menester sin licencia de la justicia de la dicha villa. Otro sí que las dichas naborías de arriba declaradas no sean osados de sembrar ni siembren en los ejidos de esta dicha villa so pena de que por ]f. 5] ello serán castigados y que los ganados se lo puedan comer y pastar. Otro si que los caminos, entradas y salidas que de esta villa salen y entran que van por el dicho sitio que los dejen libres y desembarazados, y tan anchos como por los señores del cabildo y por cualesquiera de ellos les fuere señalados. Otro si que sean obligados a dar mensajeros para Oaxaca y México cuando se ofreciere cosas tocantes al bien y pro de la república, y ansí en esto como en las cosas que fueren menester para reparar las azoteas de la iglesia y monasterio del señor Santo Domingo, y que demás de esto sean tenidos a guardar lo que en la Puebla y en otras partes suelen hacer y hacen. Otro si que las dichas naborías según dicho es sean obligadas si alguna vez por caso [f. $5 \mathrm{v}$ ] fortuito hubiere algún fuego, que sean obligados en oyendo la campana en venir y ayudar a pagar el dicho fuego e con las dichas condiciones como dicho es de suso declaradas, dijeron que como dicho tienen les hacían bien y merced y que mandaban y mandaron a mí el dicho escribano que lo asiente en el libro de cabildo de esta dicha villa, y que a las naborías se les de un traslado del dicho título, y esto dijeron que mandaban y mandaron, y lo firmaron de sus nombres, en el libro del cabildo Juan Antonio y Fernán Gómez de Cabildo alcaldes, Juan de Aldaz, Bartolomé de Alcántara al dicho sed_[sic] Juan Bautista de Escobar. Yo Juan Manzano escribano público y del consejo de esta dicha villa doy fe y verda [f. 6] dero testimonio que pasó ante mí todo lo susodicho. Y porque puedan, lo firmé de mi nombre. Juan Manzano público de cabildo.

En la Ciudad de México 16 días del mes de marzo de 1552 años visto por el excelentísimo señor don Luis de Velasco visorrey y gobernador por su majestad en esta Nueva España: a el sitio que 
fue dado por el cabildo justicia regimiento de la villa de Santilifonso de los Zaapottecaspa donde puedan poblar las naborías que hay en la dicha villa, y los demás que a dicho sitio de otras partes se quisieren venir a poblar en él, dijo que aprobaba y aprobó el sitio que así les fue dado por el dicho cabildo y en nombre de su majestad se necesario fuera, de nuevo les hacía merced de él y mandaba y mandó que el alcalde [f. 6v] mayor que es o fuere de la dicha provincia, les señale en los baldíos y partes sin perjuicio con parecer del cabildo, tierras donde puedan labrar y hacer sus sementeras para su sustentación y que la licencia que se les diere para sacar alguna agua, sea sin que se les lleve, por razón de ello, cosa alguna y que los caminos reales que pasaren por el dicho sitio, los dejen libres y desembarazados de la manera que por el dicho alcalde mayor se declare, y que en caso que se ofrezca ser necesario traer algún despacho que convenga al servicio de su majestad y bien de aquella villa, sea pagándoles primeramente a dichos indios que los trajeren su trabajo en presencia del alcalde mayor, y no de otra manera, y lo que el dicho alcalde mayor les tasare, y que así mismo cuando se ofreciere algún caso fortuito de fuego en la dicha villa, sean tenidos a [f. 7] ir al dicho socorro de él, y que a los dichos indios naborías no se les pida ni lleve otros tributos ni servicio alguno, y como personas libres y vasallos de su majestad, puedan vivir y morar en el dicho sitio y del amparo y defendimiento de ellos y se les administrar justicia en los casos que se les ofrecieren, tenga cargo el alcalde mayor de la dicha villa, y por su ausencia la justicia ordinaria de ella. Y que todo esto que dicho es se asiente en el libro de cabildo de la dicha villa para que se guarde y no vayan contra él, y en fe de ello fecho ut supra. don Luis de Velasco. Por mandado de su excelencia. Santiago Jurado.

En la villa de Santi Ildefonso, que es de la provincia de los Zaapottecas de esta Nueva España, a seis días del mes de mayo de 1553 años yo Alonso de Suisca alcalde mayor en esta [f. 7v] dicha villa y sus provincias por su majestad: en cumplimiento de lo en este mandamiento del ilustrísimo señor virrey de esta Nueva España, contenido en él y estando presentes los señores alcaldes ordinarios y regidores, cabildo de esta dicha villa, conviene a saber Juan de Aldas y Juan Gómez Alcaldes, y Juan Martínez y Bartolomé de Alcántara regidores, y los reverendos padres fray Domingo de Monterey y fray Fabián Ignacio Antonio, vicario de esta dicha villa, por ellos fueron presentes los dichos naboríos contenidos en el dicho mandamiento, y me pidieron el cumplimiento de él les de y entregue la posesión del dicho sitio de que les tiene hecho composición los de esta villa y su señoría ilustrísima confirmado, y en nombre de su majestad, para que ellos [f. 8]quieren labrar luego y hacer sus casas como su señoría manda en el dicho mandamiento, el cual yo le di en presencia de todos los dichos, y lo firmé de mi nombre: ut supra. Alonso de Luyca. Pasó ante mí Pedro García escribano nombrado.

En la ciudad de México a 28 días del mes de febrero de 1567 años. El muy excelente señor don Gastón de Peralta Marqués de Falces, conde de Santi Esteban, mayordomo mayor de su majestad del reino de Navarra, y su visorrey, gobernador y capitán general en esta Nueva España, y presidente de la Audiencia real que en ella reside, habiendo visto el asiento tomado entre los vecinos españoles de la Villa de Sant Idelfonso de los indios mexicanos que po [f. 8v] blaron en la dicha villa su fecha a 15 días del mes de febrero del año pasado de 1552, en la confirmación hecha por el ilustrísimo don Luis de Velasco, visorrey que fue de esta Nueva España, en 17 días del mes de marzo del dicho año, su excelencia dijo que lo confirmaba y aprobaba y la confirmó y aprobó sin perjuicio del tributo de su majestad, el cual sin embargo de ello, paguen cuando les fuere echado y repartido y en todo lo demás se guarde y cumpla el dicho asiento y confirmación de él, como en él se contiene y conforme al dicho asiento y concierto, se les de y señalen a los dichos indios tierras para que labren y hagan sementeras, y así lo mandó y firmó de su nombre. El Marqués [f. 9] de Falces. Por mandado de su excelencia, Juan de Cubas.

En la villa de San Idelfonso de la Nueva España a 30 días del mes de abril de 1567 años. Ante el muy magnífico señor Fernando Dávalos alcalde mayor por su majestad de la villa de el de Nejapa y Provincia de los Zaapottecas presentaron el mandamiento de esta otra parte confirmado del 
muy excelente señor visorrey de esta Nueva España Fernando Martín y Diego Santiago indios alcaldes, y Juan de Velasco principal, y otros indios de la estancia y pueblo de Papalotiquipaqui, y mediante Andrés Manzano intérprete del juzgado juramentado en forma pidieron a su merced lo mande guardar y cumplir, y por el señor alcalde [f. 9v] mayor visto lo obedeció con el debido acatamiento, y en cuanto a su cumplimiento mandaba y mandó se cumpla y guarde como en él se contiene, y lo firmó de su mano. Fernando Dávalos. Pasó ante mi Fernando López escribano.

Don Martín Enríquez visorrey gobernador y capitán general por su majestad de esta Nueva España y presidente de su audiencia real que en ella reside. Os hago saber a vos el alcalde mayor de la villa y Provincia de los Zaapottecas, y a otras cualesquiera justicia de la dicha provincia, que por parte de los naturales de ella me ha sido hecha relación, que vos las dichas justicias y otros vecinos españoles les enviáis cargados de unas partes a otras por tamemes de que les hacen mucho agravio, y que si no se remediare vendrán [f. 10] en mucha disminución los naturales y me pidieron lo mandase remediar, y porque como sabéis su majestad tiene proveído y mandado no se carguen tamemes, por la presente os mando veáis la provisión real en el caso por su majestad dada, y la guardéis y cumpláis en todo y por todo, como en ella se contiene, y contra el tenor y firma de ella no consintáis en que carguen tamemes, so las penas en la dicha provisión confirmadas, los cuales tendréis cuidado de las ejecutar en los que contra ella fueren y pasaren, sin remisión alguna. Fecha en México a 11 días del mes de septiembre de 1570 años (entiéndase que se da a pedimento de los indios naboríos del pueblo de Analco. Fecho ut supra. Domingo Enríquez. Por mandado de [f. 10v] su excelencia Juan de Cuevas.

En la Ciudad de México a 7 día del mes de septiembre de 1570 años el muy excelente señor don Martín Enríquez visorrey gobernador y capitán general por su majestad de esta Nueva España, y presidente de la audiencia real que en ella reside, habiendo visto la escritura de asiento fecha entre la justicia y regimiento de la villa de San Idelfonso de la Provincia de los Zaapottecas, y los indios naborías que a la dicha villa se han ido a poblar, y la confirmación de ella fecha por el muy ilustre don Luis de Velasco visorrey y gobernador que fue de esta Nueva España en 16 días del mes de marzo del año pasado de 1552 años, dijo: que cuanto [f. 11] ha lugar de derecho aprobaba y confirmaba y aprobó y confirmó la dicha escritura y confirmación con los aditamentos en la tal confirmación contenidos, y mandó se guarde cumpla y no se vaya contra ella, y las justicias de la dicha villa le hagan guardar y cumplir y que no se vaya contra ello. Don Martín Enríquez. Por mandado de su excelencia. Juan de Cuevas.

En la villa de San Ildefonso a 3 días del mes de agosto de 1579 años: Fernando Paranillo, juez de residencia por su majestad en esta dicha villa: los indios del pueblo de Analco, barrio de esta dicha villa, presentaron la provisión real de su majestad, y mandamiento de los señores visorreyes y del muy [f. 11v] excelente señor visorrey de esta Nueva España, que habiéndolo visto el dicho señor juez de residencia, tomó la provisión real y la besó y puso sobre su cabeza, y la obedeció como carta y provisión real de su majestad, y los demás mandamientos, obedeció y en cuanto al cumplimiento, mandó que no den ni consientan que ningún indio del barrio de Analco vaya con carga de tamemes contra el tenor de dicho mandamiento, so las penas en él contenidas, y si en ello se les hiciere fuerza, que luego acudan con todo ello a las justicias de su majestad para que se les haga, guarde y cumpla lo que su majestad manda, y sus muy excelentes señores visorreyes de esta Nueva España. Fernando Paranillo.

En la ciudad de México a 31 [f. 12] días del mes de julio de 1589 años Don Álvaro Manrique de Zúñiga Marqués de Villamanrique, virrey lugarteniente del rey nuestro señor y su gobernador y capitán general en este Nueva España, y presidente de la audiencia y cancillería real que en ella reside y etc. Habiendo visto estos mandamientos, y confirmaciones atrás contenidos, dados por los visorreyes don Antonio de Mendoza, don Luis de Velasco, Marqués de Falces y don Martín Enríquez, en razón del sitio y tierras que se dio y señaló a los indios mexicanos en el pueblo de 
Analco, junto a la villa de San Ildefonso con ciertas condiciones, y lo pedido por dichos indios, sobre que se les guarde y cumpla dijo: que mandaba y mandó se guarden, cumplan y ejecuten [f. 12v] los dichos mandamientos y autos de confirmación de ellos, según y como en ellos se contiene, y las justicias de su majestad, no consientan se excedan ni vayan contra ellas, ni se haga ninguna novedad, castigando con rigor a los que pretendieren innovarlo. Don Álvaro Manríquez. ante mí Joan de Cuevas.

Don Luis de Velasco caballero de la orden de Santiago, virrey lugarteniente del rey nuestro señor, su gobernador y capitán general de esta Nueva España y presidente de la Audiencia real que en ella reside y etc. A vos el alcalde mayor de la villa de San Ildefonso, sabed que los indios mexicanos que viven en el barrio de Analco, junto a esta dicha villa, me han hecho relación que como es notorio ellos quedaron avecindados en aquella parte desde que sus padres y abuelos fueron en ayuda de los españoles que salieron a conquistar y [f. 13] ganar toda aquella provincia, y que por esta razón todos los virreyes mis antecesores los han favorecido y honrado ansí en reservarles de pagar tributo como repartiéndoles tierras con que se pudiesen sustentar y que de algunos días a estar parte los vecinos de la dicha villa y justicias de ella y de su comarca los traen vejados y molestados haciéndoles ir contra su voluntad en otros ministerios y cosas de su aprovisionamiento, muchas veces sin pagarles su trabajo diciendo se ocupan en servicio de su majestad en que recibían notorio agravio para cuyo remedio me pidieron les mandase dar un mandamiento para que no fuesen compelidos hacer los dichos servicios contra su voluntad y que si con ello algunas veces quisieren acudir fuese satisfaciéndoles su [f. 13v] trabajo y por mi visto por la presente os mando que no consintáis ni deis lugar que los dichos indios mexicanos naturales de dicho barrio de Analco se les compela ni apremie a que sirvan contra su voluntad en cosa alguna ni a que salgan fuera de su natural con los dichos despachos y si ellos lo quisieren hacer sea pagándoles su trabajo por la forma y orden que está dada sin que se les haga agravio. Fecho en México a 22 de agosto de 1591 años. Don Luis de Velasco. Por mandado del virrey Pedro de Campos ${ }^{32}$.

En el pueblo de Analco arrabal de la villa de San Ildefonso Provincia de los Sapotecas de esta Nueva España en 20 días del mes de marzo de 1593 años, ante Nicolás de Espíndola, alcalde mayor de este dicho pueblo, y Antonio Ignacio y Lucas Fernández, Pedro Jiménez y otros [f. 14] indios principales y naturales de dicho pueblo, y presentado el mandamiento de esta otra parte, y le pidieron al dicho alcalde mayor se guarde el cumplimiento de él, y por dicho alcalde mayor visto y leído, fue obedecido en forma y en punto muy al cumplimiento de él: dijo que está presto a lo guardar y cumplir, según y como en él se contiene, estando presentes por testigos Diego Dávila, alcalde ordinario, y Miguel de Alcántara, y Rodrigo Canseco, Nicolás de Espíndola. Por ante mí Juan de Ojeda escribano.

Concuerda con los recaudos que en un cuaderno de nueve fojas en papel común de letra antigua, maltratada y rotas dichas fojas presentó para este efecto la república del barrio de Analco de esta jurisdicción, a quien se las devolví rubricadas del presente escribano y este testimonio a continuación de [roto] [f. 14v] fojas con esta primera y su correspondiente de el sello cuarto y las demás del común, corregidas y concertadas al [roto] con el original por ser la letra muy antigua y algunos vocablos rotos e ininteligibles. Es dado por mandato del señor alcalde mayor de esta jurisdicción de Villa Alta en su auto que antecede a 22 días del mes de septiembre de 1771 años siendo testigos don Joaquín Sierra Taguer, don José Antonio Pérez de Salazar y José Antonio Ledesma. Entre renglones: los, don Antonio, sobre raído, título, con. Vale.

En testimonio de verdad Joseph de Huidobro

Escribano real y receptor [rúbrica] 


\section{BIBLIOGRAPHY}

Barros van Hövelltot Westerflier, A. (2007). Cien años de guerras mixes: territorialidades prehispánicas, expansión burocrática y zapotequización en el Istmo de Tehuantepec durante el siglo XVI. Historia mexicana, LVII(2) (226), 325-403.

Blom, F. (1945). El Lienzo de Analco, Oaxaca. Cuadernos americanos, XXIV(4), 125-136.

Celestino, E. (1991). El Señorío de San Esteban del Saltillo. Voz y escritura nahuas, siglos XVII y XVIII. Saltillo: Archivo Municipal de Saltillo.

Chance, J. (1976, noviembre). The Urban Indian in Colonial Oaxaca. American Ethnologist, III(4), 603-632.

Chance, J. (1998). La conquista de la sierra: españoles e indígenas de Oaxaca en la época de la Colonia. México: Instituto Oaxaqueño de las Culturas, Fondo Estatal para la Cultura y las Artes-Centro de Investigaciones y Estudios Superiores en Antropología Social.

Coordinación General del Comité Estatal de Planeación para el Desarrollo de Oaxaca, COPLADE (2017). Diagnóstico Regional Sierra Norte. Oaxaca: Universidad de la Sierra de Juárez.

Dakin, K. y Lutz, C. (1996). Nuestro Pesar, Nuestra Aflicción: Memorias en lengua náhuatl enviadas a Felipe II por indigenas del valle de Guatemala hacia 1572. México: Universidad Nacional Autónoma de México, Centro de Investigaciones Regionales de Mesoamérica.

Díaz del Castillo, B. (1939). Historia verdadera de la conquista de la Nueva España. México: Pedro Robredo.

Güereca, R. (2016). Milicias indígenas en la Nueva España. Reflexiones del derecho indiano sobre los derechos de guerra. México: Instituto de Investigaciones Jurídicas, UNAM.

Güereca, R. (2018). Caciques, 'lenguas' y soldados fronterizos: actores indígenas en la conquista del Nayar, (1721-1722). México: el autor.

Güereca, R. (2020). El Lienzo de Analco: reconstruyendo una narrativa indígena de la conquista. Revista Euroamericana de Antropología, 9, 17-31.

König, V. (1993). Die Schlachtbei Sieben Blume: Konquistadoren, Kazikenund Konflikteaufalten Landkarten der Indianer Südmexikos. Bremen: Edition Temen.

König, V. (2010). La Batalla de Siete Flor: conquistadores, caciques y conflictos en mapas antiguos de los zapotecos, chinantecos y mixes. Oaxaca: Secretaría de Culturas y Artes del Gobierno de Oaxaca.

Martínez Baracs, A. (1993, octubre-diciembre). Colonizaciones tlaxcaltecas. Historia mexicana, XLIII(2) (170), 195-250.

Matthew, L. E y Oudijk, M. R. (Eds.). (2007). Indian Conquistadors. Indigenous Allies in the Conquest of Mesoamerica. Oklahoma: Universidad de Oklahoma.

Oudijk, M. (1995). The Second Conquest: An Ethnohistory of a Cajonos Zapotec Village \& The Lienzo of Tabaá I. Leiden: Universidad de Leiden.

Rafael, P. (2019). El Lienzo de Analco. Interpretación iconográfica de un lienzo perteneciente a los indígenas conquistadores de la Sierra Norte de Oaxaca. Xalapa: el autor.

Sego, E. (1998). Aliados y adversarios: los colonos tlaxcaltecas en la frontera septentrional de Nueva España. México: El Colegio de San Luis, Gobierno del Estado de 
Tlaxcala, Centro de Investigaciones Históricas de San Luis Potosí.

Sousa, L. (2017). El náhuatl colonial de Villa Alta: comunidades mixes y el arte de la escritura alfabética en lenguas indígenas. Tlalocan, 22, 45-63.

Valdés, C. y Dávila, I. (1999). Los tlaxcaltecas en Coahuila. $2^{\text {a }}$ ed., San Luis Potosí, El Colegio de San Luis, Gobierno del Estado de Tlaxcala.

Yannakakis, Y. (2007). The Indios Conquistadores of Oaxaca's Sierra Norte. From Indian Conquerors to Local Indians. En L. E. Matthew, y M. R. Oudijk, (Eds.), Indian Conquistadors. Indigenous Allies in the Conquest of Mesoamerica, (pp. 227-253). Oklahoma: Universidad de Oklahoma.

Yannakakis, Y. (2008). The Art of Being In-Between. Natives Intermediaries, Indian Identity, and Local Rule in Colonial Oaxaca. Durham: Duke University Press.

Yannakakis, Y. (2011). Allies or Servants? The Journey of Indian Conquistadors in the Lienzo of Analco. Ethnohistory, XLVIII(4), 653-682.

\section{NOTES}

1. Archivo General de Indias (en adelante, AGI), Patronato, 61, N.2, R.1, f. 4.

2. AGI, Patronato, 66A, N. 2, R. 5, ff. 2v, 4; AGI, Patronato, 84, N. 2, R. 2, ff. 6v, 9.

3. AGI, Patronato, 61, N.2, R.1, f. $5 \mathrm{v}$.

4. Sobre indios aliados y auxiliares de los españoles, ver Matthew y Oudijk (2007).

5. Archivo Histórico Judicial de Oaxaca (en adelante, AHJO), sección Villa Alta, serie Civil, legajo 2, exp. 10, f. 1 .

6. Sobre el contexto de esta donación, ver la nota 13.

7. Desde su surgimiento, la investigación genealógica ha estado en el centro de las preocupaciones de los practicantes mormones, pues uno de sus compromisos religiosos consiste en buscar a sus ancestros para convertirlos a su religión. De ahí que, desde 1894, se haya fundado la Sociedad Genealógica de Utah y en 1938 hayan iniciado la microfilmación de archivos, principalmente municipales y parroquiales, de todo el mundo, en el marco de convenios con los diferentes gobiernos nacionales.

8. Archivo General de la Nación, México (en adelante, AGN), Indios, vol. 36, exp. 8, f. 6-7; y AGN, Indios, vol. 36, exp. 105, fs. 101-102v.

9. Esta confusión entre San Juan Evangelista Analco y el barrio de Analco en Villa Alta no es infrecuente: la propia Viola König, en su estudio sobre lienzos y mapas indígenas de la Sierra Norte de Oaxaca, ubica el origen del Lienzo de Analco no en el barrio de mexicanos, sino en el pueblo zapoteco de San Juan Evangelista Analco (König, 2010, p. 90).

10. IJSUD, FHL, Mexico, Oaxaca, Church Records, microfilme 004782319, imagen 280. Salt Lake City, [En línea], disponible en: https://www.familysearch.org [Consultado el 10 de julio de 2020].

11. IJSUD, FHL, Mexico, Oaxaca, Church Records, microfilme 4782319, imágenes 541 a 558 . Salt Lake City, [En línea], disponible en: https://www.familysearch.org [Consultado el 10 de julio de 2020].

12. IJSUD, FHL, Mexico, Oaxaca, Church Records, microfilme 004782319, imagen 476. Salt Lake City, [En línea], disponible en: https://www.familysearch.org [Consultado el 10 de julio de 2020].

13. Eugenio Sosa Rodríguez fue el donador del lienzo. Años más tarde, en una carta al presidente de México, afirmó que el lienzo había estado empotrado en uno de los muros de la iglesia de Villa Alta la que, al derrumbarse, sepultó el lienzo en escombros, de donde Sosa lo rescató para luego comprarlo y, dada su importancia, decidió donarlo como testimonio de la "historia de la patria": "Carta de Eugenio Sosa Rodríguez al C. Licenciado Luis Echeverría Alvarez, Presidente 
Constitucional de los Estados Unidos Mexicanos", 12 de julio de 1973, Archivo Institucional Histórico del Instituto Nacional de Antropología e Historia (INAH), Dirección General, Códices, Caja 2, Folder 6, f. 4. Agradezco a Michel R. Oudijk la noticia sobre la existencia de este documento.

14. Los otros cuatro documentos del siglo XVI son: un libro de defunciones de la parroquia de San Miguel Sola de Vega fechado en 1563-1678 (microfilme número 4768950); un libro de bautismos de San Pablo Huitzo de 1578-1714 cuyos primeros registros, en realidad, datan de 1576 y están escritos en mixteco (microfilme número 4240962); un libro de matrimonios de indios de la parroquia de San Pedro y San Pablo Tequixtepec de 1591-1668 también con registros en lengua indígena (microfilme número 4253455); un libro de cofradías de la parroquia de San Juan Bautista Coixtlahuaca que va de 1593 a 1830 (microfilme número 4765514).

15. Este encabezado solo nos dice la fecha en que se elaboró el documento: "En 24 días del mes de diciembre, los escribanos aquí están/dejan constancia".

16. Sobre las colonias tlaxcaltecas establecidas en el septentrión novohispano en 1591 por acuerdo con el virrey Luis de Velasco para apoyar la pacificación de la región, véase Martínez Baracs (1993); Sego (1998); Valdés y Dávila (1999).

17. IJSUD, FHL, Mexico, Oaxaca, Church Records, microfilme 004782319, imagen 471. Salt Lake City, [En línea], disponible en:https://www.familysearch.org [Consultado el 10 de julio de 2020].

18. APVA, Papeles de Analco, exp. 2, f. 4.

19. AHJO, sección Villa Alta, serie Civil, legajo 17, exp. 17, f. 10v.

20. Por ejemplo, los tlaxcaltecas suelen llevar una cinta blanca y roja entrelazada alrededor de la cabeza, anudada sobre la frente, y detrás plumas de garza.

21. Ver la transcripción de la selección documental.

22. APVA, Papeles de Analco, exp. 1, f. 2v.

23. AGI, Justicia, 291.

24. Por ejemplo, en AGI, México, 203, N. 24; AGI, México, 203, N. 26; AGI, México, 208, N. 8; AGI, México, 208, N. 24; AGI, Patronato, 20, N. 5, R. 1; AGI, Patronato, 76, N. 6, R. 12; AGI, Patronato, 84, N. 2, R. 2; AGI, Patronato, 20, N. 5, R. 1; AGI, Patronato, 73, N. 1, R. 4; AGI, Patronato, 72, R. 4; AGI, Guatemala, 110, N. 8 .

25. APVA, Papeles de Analco, exp. 4, f. 3.

26. APVA, Papeles de Analco, exp. 6, f. 4.

27. APVA, Papeles de Analco, exp. 4, f. 10.

28. APVA, Papeles de Analco, exp. 1, f. 23v.

29. Por ejemplo, en 1767 afirmaron que solo algunos indios de Analco eran descendientes de los conquistadores, "siendo como son los más indios intrusos en dicho barrio, ya descendientes del pueblo de Xalatlaco de la ciudad de Oaxaca, ya de nuestro pueblo, ya del de Cajonos, de Yaxila, y de otros así de esta jurisdicción como de varias". Para confirmar su dicho, presentaron a varios testigos que afirmaron que solo tres hombres eran "descendientes legítimos de los naturales que fundaron Analco y recibieron el privilegio de soldados y no pagar tributos": AHJO, serie Villa Alta, Sección Civil, legajo 21, exp. 25, f. 3 y siguientes.

30. Ver transcripción del documento.

31. En varias partes del documento aparecen guiones que el escribano utilizó para indicar las partes que le resultaban ilegibles. Es indicativo de que el escribano que hizo la copia en 1771 no estaba familiarizado con documentos y tipos de letra del siglo XVI. De ahí que en algunas partes la redacción del texto sea extraña o inconsistente.

32. Este mismo documento se encuentra también en AGN, Indios, vol. 3, exp. 917. 


\section{ABSTRACTS}

The objective of this text is to present a documentary file concerning the agrarian history of Analco, an Indigenous town located in the Sierra Norte de Oaxaca, Mexico. To contextualize the file, the history of this settlement and its regional importance, as well as the place it has occupied in historiography, is first explained. Next, the originals kept in the Villa Alta Parish Historical Archive are compared with the microfilming carried out in 1978 to show the losses suffered by the documentation. It also analyzes the contribution of the file to the early history of this settlement.

El objetivo de este texto es presentar un legajo documental concerniente a la historia agraria de Analco, un pueblo de indios ubicado en la Sierra Norte de Oaxaca, México. Para contextualizar el legajo, se explica primeramente la historia de este asentamiento y su importancia regional, así como el lugar que ha ocupado en la historiografía. A continuación, se comparan los originales resguardados en el Archivo Histórico Parroquial de Villa Alta con la microfilmación llevada a cabo en 1978 para mostrar las pérdidas que ha sufrido la documentación. Se analiza también lo que el legajo nos aporta sobre la historia temprana de este asentamiento.

INDEX

Keywords: Analco, naborías, mexicanos, náhuatl, Oaxaca

Palabras claves: Analco, naborías, mexicanos, náhuatl, Oaxaca

\section{AUTHOR}

\section{RAQUEL E. GÜERECA DURÁN}

Instituto de Investigaciones Históricas, Universidad Nacional Autónoma de México, México Correo electrónico: raquelguereca@unam.mx 